\section{Reply to the Response to TALmale \& Tiple, 2013 BY S. JOSHI}

\section{S.S. Talmale ${ }^{1} \&$ Ashish Tiple ${ }^{2}$}

${ }^{1}$ Zoological Survey of India, Central Zone Regional Centre,168-169, Scheme No. 5, Vijayanagar, Jabalpur, Madhya Pradesh 482002, India

${ }^{2}$ Department of Zoology, Vidyabharti College, Seloo, Wardha, Maharashtra 442104, India

${ }^{1}$ s_talmale@yahoo.co.in (corresponding author), 2ªshishdtiple@yahoo.co.in

We appreciate the response to our paper (Talmale \& Tiple 2013) by Shatanu Joshi (2013). We have provided details for identification along with image. The identification is based totally on Fraser (1933) with authentic identification key for Odonata from the Indian region. The detail of images are given in the text are of wet specimen (preserved in alcohol) hence the pale colouration.

We are aware about the taxonomy of the species under the genus Lestes which is not settled and the same was depicted in the text. The species Lestes concinnus is only reported from Meghalaya, India (Prasad \& Varshney 1995). Its occurrence, distribution or description of specimens from peninsular India is not yet published. Reports from Andhra Pradesh, Gujarat, Maharashtra, Uttar Pradesh and West Bengal are by Lahiri (1987) on the basis of synonymy of Lestes umbrinus under L. concinnus following Lieftinck (1960). However, umbrinus is listed as a separate species by Prasad \& Varshney (1995), Mitra (2002), Subramanian (2009), and by Martin \& Dennis in their World List of Odonata (last revision 21 February 2013).

The description of anal appendages of $L$. concinnus provided by Lahiri (1987) is different than of $L$. thoracicus. Figure No. 137 and 138 on page number 309 in Lahiri (1987) reveals that superiors do not show finely denticulate inner margin in L. concinnus as well as in $L$. umbrinus as reported by Fraser (1933). So, identified specimens are of Lestes thoracicus only. It is known from Bihar (Prasad \& Varshney 1988), Chhattisgarh (Prasad 1996), Gujarat, Odisha, Uttarakhand, Uttar Pradesh, and West Bengal (Sharma 2010).

Asahina (1985) provided the description of $L$. thoracicus of Thailand region, which does

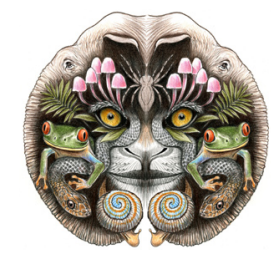

ISSN

Online 0974-7907 Print 0974-7893

\section{OPEN ACCESS} not mean a match with the Indian form. A numbers of individual variations are seen within species on regional or geographic level in lower animal groups like damselflies. As an example, Fraser (1933) reported Copera marginipes (Rambur) as a single species occurring in Ceylon (Sri Lanka), Coorg, West Coast, Deccan, Assam and Bengal. Mitra (2002) remarked intraspecific variations in $L$. umbrinus from Bihar and Odisha. Therefore, It is necessary to review the whole genus and species of Indian region with revised identification key. It is welcome if someone comes forward to complete this herculean task.

\section{REFEENCES}

Asahina, S. (1985). A list of the Odonata from Thailand. Part VIII Lestidae. Chô Chô 8(8): 2-13.

Fraser, F.C. (1933). The fauna of British India, including Ceylon and Burma, Odonata Vol. I. Taylor and Francis Ltd., London 1-423.

Joshi, S. (2013). Response to "Talmale, S.S. \& A.D. Tiple (2013). New records of damselfly Lestes thoracicus Laidlaw, 1920 (Odonata: Zygoptera: Lestidae) from Maharashtra and Madhya Pradesh states, central India" with a note on identification of Lestes concinnus Hagen in Selys, 1862 and L. umbrinus (Selys, 1891). Journal of Threatened Taxa 5(7): 4125-4126; http://dx.doi.org/10.11609/ JoTT.03546.4125-6

Lahiri, A.R. (1987). Studies on the Odonate fauna of Meghalaya. Records of the Zoological Survey of India, Occasional Paper No. 99: 1-402.

Lieftinck, M. A. (1960). On the Identity of some little known Southeast Asiatic Odonata in European Museums described by E. de Selys Longchamps with descriptions of new species. Memoirs of Society of Entomology of Italy 38: 229-256.

Martin, S. \& P. Dennis (2013). World List of Odonata. Last revision on 21 February, 2013 downloaded from http://www.pugetsound.

DOI: http://dx.doi.org/10.11609/JoTT.03560.4127-8

Date of publication: 26 April 2013 (online \& print)

Manuscript details: Ms \# 03560 | Received 16 March 2013

Citation: Talmale, S.S. \& A. Tiple (2013). Reply to the Response to Talmale \& Tiple, 2013 by S. Joshi. Journal of Threatened Taxa 5(7): 4127-4128; http://dx.doi. org/10.11609/JoTT.03560.4127-8

Copyright: ( $C$ Talmale \& Tiple 2013. Creative Commons Attribution 3.0 Unported License. JoTT allows unrestricted use of this article in any medium, reproduction and distribution by providing adequate credit to the authors and the source of publication. 
edu/academics/academic-resources/slater-museum/biodiversity resources/dragonflies/world-odonata-list.

Mitra, T.R. (2002). Geographic distribution of Odonata (Insecta) of Eastern India. Memoirs of the Zoological Survey of India 19(1): 1-208.

Prasad, M. (1996). Studies on the Odonata fauna of Bastar, Madhya Pradesh, India. Records of the Zoological Survey of India. 95: 165213.

Prasad, M. \& R.K. Varshney (1988). The Odonata of Bihar, India. Records of the Zoological Survey of India, Occasional Paper No. 110 1-45.

Prasad, M. \& R.K. Varshney (1995). A check list of the Odonata of India including data on larval studies. Oriental Insects 29: 385-428; http://dx.doi.org/10.1080/00305316.1995.10433748

Sharma, G. (2010). Lestes thoracicus. In: IUCN 2011. IUCN Red List of Threatened Species. Version 2011.2. <www.iucnredlist.org>. Downloaded on 20 December 2011.

Subramanian, K.A. (2009). A Checklist of Odonata of India. Zoologica Survey of India, 36pp.

Talmale, S.S. \& A.D. Tiple (2013). New records of damselfly Lestes thoracicus Laidlaw, 1920 (Odonata: Zygoptera: Lestidae) from Maharashtra and Madhya Pradesh states, central India. Journal of Threatened Taxa 5(1): 3552-3555; http://dx.doi.org/10.11609/ JoTT.03264.947
Albert Orr, the Subject Editor's reply to the response:

The editor agrees that the conclusions drawn by the correspondent are probably correct, principally based on the general appearance of the insect. Nevertheless it should be noted that some of the arguments are based on literature which is itself open to question. It is very doubtful if Asahina had seen the type and thus his interpretation must be treated with caution. Other cited literature is also of dubious value. Ultimately to confidently resolve a disputed identity such as this it is necessary to have access to the specimen and to original type material. 